\title{
Pendidikan Seni Tari Sanggar Seni Sarwi Retno Budaya Surakarta Sebagai Pengembangan Karakter Anak
}

\author{
Laras Ambika Resi ${ }^{1}$, Sutarno Haryono ${ }^{2}$, Slamet Subiyantoro ${ }^{3}$ \\ Prodi Pendidikan Seni, Pascasarjana Fakultas Keguruan dan Ilmu Pendidikan \\ Universitas Sebelas Maret Surakarta, Jalan Ir. Sutami 36 A Jebres, Surakarta, Indonesia
}

'larasambikaresi@gmail.com

Penelitian ini adalah untuk mengkaji pendidikan seni tari di sanggar seni Sarwi Retno Budaya Surakarta sebagai pengembangan karakter anak. Metodologi penelitiannya bersifat kualitatif dengan pendekatan kritik seni holistik yang menggunakan rujukan teori: (1) Pembelajaran, (2) Pendidikan Karakter, (3) Seni Pertunjukan, dan (4) Komunikasi. Adapun teknik pengumpulan datanya melalui: studi pustaka, wawancara, observasi, dan dokumentasi. Teknik analisisnya menggunakan cara-cara kualitatif yaitu seluruh kegiatan atau aktifitas analisisnya dilakukan bersamaan dengan proses atau waktu pengumpulan data dan pada bagian akhir data-data yang bersifat genetik, objektif dan afektif dikaji secara integratif untuk menarik simpulan sebagai makna tunggal yang menempatkan posisi setiap temuan berada pada satu kesatuan konteks. Hasil temuan penelitian ini bahwa pendidikan seni tari di sanggar seni Sarwi Retno Budaya mampu mendidik penari profesional yang memiliki nilai-nilai karakter sebagai pengembangan karakter anak supaya memiliki kepribadian yang bertanggungjawab untuk menjaga, melestarikan dan mengembangkan peradaban budaya bangsa Indonesia. Adapun nilai-nilai karakter yang ditanamkan terhadap anak-anak atau siswa sanggar seni Sarwi Retno Budaya yaitu: nilai spiritual, nilai kejujuran, nilai santun, nilai kerjasama, nilai tenggang rasa, nilai disiplin, nilai kreatif, dan nilai tanggungjawab.

Kata kunci: pendidikan, seni tari, nilai-nilai karakter, sanggar seni Sarwi Retno Budaya.

\section{Dance Education In Sarwi Retno Budaya Art Studio Surakarta as a Medium For Developing Children's Character}

This research studies dance education in Sarwi Retno Budaya art studio in Surakarta as a means of character development in children. A qualitative research methodology is used with a holistic art criticism approach using references to theories of: (1) Learning, (2) Character Education, (3) Performing Arts, and (4) Communication. The data collection technique includes a library study, interviews, observation, and documentation. The analysis technique uses qualitative methods in which the analysis of all the activities is carried out together with the process or time of data collection, and in the final stage, the genetic, objective and affective data are studied integratively to draw a conclusion as a single meaning which positions each finding in a single unity of context. The research findings show that the dance education in Sarwi Retno Budaya art studio is able to educate professional dancers with values of character as a means of character development in children so that they become individuals who are responsible for safeguarding, preserving, and developing the cultural civilization of the Indonesian nation. The values of character instilled in the children or students at Sarwi Retno Budaya art studio are: spiritual values, values of honesty, values of politeness, values of cooperation, values of tolerance, values of discipline, values of creativity, and values of responsibility.

Keywords: education, dance, values of character, Sarwi Retno Budaya art studio. 


\section{PENDAHULUAN}

Pendidikan adalah segala kegiatan pembelajaran yang berlangsung sepanjang jaman dalam segala situasi kegiatan kehidupan (Suparlan Suhartono, 2008:79). Pendidikan berlangsung disegala jenis, bentuk, dan tingkat lingkungan hidup yang kemudian mendorong pertumbuhan segala potensi yang ada di dalam diri individu. Pendidikan melalui proses pembelajaran memberikan dampak yang berpengaruh terhadap perkembangan anak. Kegiatan pembelajaran mampu mengubah dan mengembangkan manusia menjadi semakin dewasa, cerdas, dan matang. Pendidikan akan mewujudkan suatu potensi kejiwaan cipta, rasa, dan karsa yang membentuk potensi manusia untuk bertindak kreatif dan dinamis. Hal ini menjadi sebuah upaya manusia untuk mampu hidup dan berkembang. Secara singkat, pendidikan merupakan proses perubahan sikap dan perilaku seseorang atau kelompok orang dalam usaha mendewasakan manusia. Upaya untuk mengembangkan diri tersebut maka diperlukan adanya pelatihan dan pengajaran.

Pendidikan di sanggar merupakan salah satu pendidikan nonformal yang mengembangkan kreativitas, dan berpeluang untuk meningkatkan kecerdasan yang sesuai dengan potensi, bakat, minat, dan psikologi pada anak untuk membentuk karakter. Dengan sistem sanggar anak dapat belajar dengan mudah karena pelatih akan secara fokus memberikan materi tentang bidang tersebut, bebas mengekspresikan segala sesuatunya, saling belajar dari kelebihan dan kekurangan pada masing-masing dan mengasah ketrampilan sehingga anak dapat menjadi pribadi yang lebih aktif dan kreatif (Tjetjep Rohadi, 2016:5-12).

Surakarta merupakan kota budaya yang banyak terdapat sanggar-sanggar terutama sebagai kursus seni tari. Sanggar Sarwi Retno Budaya merupakan salah satu lembaga pendidikan nonformal yang mengelola dan menyelenggarakan pembelajaran seni khususnya seni tari. Pendiri sanggar seni Sarwi Retno Budaya adalah Sarwiyati Hartono yang bertempat di Serengan Jalan Solo, pada tahun 1975. Sanggar Sarwi Retno Budaya merupakan salah satu sanggar yang sangat menonjol dalam mendidik para siswa yang seluruhnya didominasi oleh anak-anak perempuan. Sarwi Retno Budaya bukan tempat pendidikan secara formal tetapi lebih merupakan sebuah wahana pembelajaran nonformal yang mengembangkan minat dan bakat anak pada kesenian khususnya dalam bidang seni tari (Sarwi, wawancara September 2016).

Sistem pendidikan seni tari di sanggar Sarwi Retno Budaya, diawali dari sebuah perencanaan yang meliputi: jadwal kegiatan, pembagian kelas berdasarkan umur, materi tari, media pembelajaran, tempat kegiatan dan pelatih atau pengajar tari. Jadwal kegiatan berlatih dilaksanakan pada sore hari setiap hari Senin sampai dengan Kamis. Pembagian materi ajar berdasarkan tingkat umur yang sudah barang tentu terdapat keterkaitannya dengan kemampuan anak dalam menguasai materi. Materi yang diajarkan adalah bentuk tari tradisi yang mengacu pada tarian istana gaya Surakarta dan tari kreasi. Kegiatan pembelajaran berlangsung dengan dukungan media elektronik. Berlangsungnya kegiatan pelatihan tari ini juga sangat ditentukan oleh kemampuan pelatih atau guru tari. Untuk itu pemilik sanggar Sarwi Retno Budaya, menyiapkan tenaga-tenaga pelatih profesional yang merupakan lulusan dari perguruan tinggi seni yang secara lebih khusus memiliki kemampuan di bidang seni tari (Hartono, wawancara Januari 2017).

Bentuk pendidikan yang dilakukan pelatih di sanggar Sarwi Retno Budaya menggunakan beberapa metode di antaranya: ceramah, tanyajawab, demonstrasi, driil, penampilan, studi mandiri dan penyajian. Beberapa metode yang dipilih diaplikasikan secara variatif dengan tujuan untuk pencapaian kemahiran baik yang bersifat fisik dan nonfisik. Pada gilirannya dengan belajar tari, siswa mampu menguasai aspek kepribadian yang mencakup ranah psikomotorik, afektif, dan kognitif. Semakin tampak bahwa pembelajaran tari memberikan kontribusi pada peningkatan tiga aspek kepribadian tersebut yang berpotensi pada pembentukan karakter. Pendidikan karakter adalah upaya yang dilakukan dengan sengaja untuk mengembangkan karakter yang baik (good character) berlandaskan kebajikan- kebajikan inti (care virtues) yang secara objektif baik bagi individu maupun masyarakat (Saptono, 2011:23). Pendidikan karakter pada hakikatnya ingin membentuk individu menjadi seorang pribadi bermoral yang dapat menghayati kebebasan dan tanggung jawabnya, dalam relasinya dengan orang lain dan dunianya di dalam komunitas pendidikan. Komunitas pendidikan ini bisa memiliki cakupan lokal, nasional, maupun internasional (antar negara). Potensi peserta didik yang akan dikembangkan seperti beriman dan bertaqwa kepada Tuhan Yang Maha Esa, berakhlak mulia, sehat, berilmu, cakap, kreatif, mandiri, dan menjadi warga negara yang demokratis serta bertanggung jawab yang pada hakikatnya adalah membentuk insan-insan yang berkarakter. Mengingat Pendidikan budi pekerti bagi para generasi penerus menjadi kata kunci yang fundamental, yang harus tertanamkan sejak dini sebagai landasan hidup bermasyarakat, berbangsa, dan bernegara (Cahya, 2016:119).

Beberapa potensi sanggar Sarwi Retno Budaya, selain sebagai wahana pendidikan karakter yang dirujuk dari penyelenggaraan pembelajaran tari secara terstruktur juga beberapa penghargaan yang diperoleh dalam berbagai peristiwa kesenian. Adapun potensi yang telah dicapai selama ini adalah beberapa penghargaan dari hasil kejuaraan lomba tari dan lomba wayang orang Anak serta festival Kethoprak. Bentuk penghargaan diantaranya: juara II tahun 1982-1983 Tari Golek Sri Rejeki Porseni SD tingkat Kodya Surakarta, tahun 1984 juara III Tari Golek Manis Porseni tingkat Kodya Surakarta. Berikutnya tahun 1985 juara II Tari Manipuren Porseni tingkat Kodya Surakarta, juara III pada tahun 1986 Tari Golek Manis Porseni 
tingkat Kodya Surakarta dan juara II lomba Tari Kukilo dalam rangka Hardiknas tingkat Kodya Surakarta. Pada tahun 1985/1986 juara I Tari Bondan pada porseni SD tingkat Jawa Tengah. Tahun 2005 mendapat Juara I dalam rangka Wayang Bocah di Gedung Wayang Orang Sriwedari. Pada tahun 2011 mendapat juara II dalam rangka Festival Kethoprak pelajar di Taman Budaya Jawa Tengah (Sarwi, wawancara Oktober 2016).

Berdasarkan paparan tersebut terdapat fenomena yang sangat menarik dan layak untuk diteliti, mengingat bentuk pendidikan tari di sanggar Sarwi Retno Budaya selain mengembangkan minat, bakat dan potensi kepenarian juga terdapat penanaman nilai-nilai kehidupan yang diharapkan mampu membentuk karakter pribadi siswa sehingga menjadi lebih mandiri dan santun dalam sikap dan perilakunya (Sarwi \& Hartono, wawancara Februari 2017). Tjetjep Rohadi menyatakan bahwa pendidikan seni pada prinsipnya adalah mengintegrasikan kemampuan fisik, intelektual dan kreativitas, serta mempertautkan pendidikan, kebudayaan, dan kesenian secara lebih dinamis dan bermakna (2016:9).

\section{METODE PENELITIAN}

Metodologi penelitian kualitatif dengan pendekatan kritik seni holistik merupakan pilihan peneliti yang tepat untuk mengungkap kasus pendidikan seni tari Sanggar Seni Sarwi Retno Budaya sebagai pengembangan karakter anak yang dapat dikaji dari keterkaitan faktor genetik, obyektif dan afektif. Faktor genetik pada kasus penelitian ini mencakup: peraturan tentang sanggar dari dinas terkait dan konsep, gagasan dari pemilik sanggar. Faktor objektif meliputi komponen pembelajaran yang terdiri dari: guru tari, media, dan siswa dengan seluruh aktivitas dalam proses pembelajarannya. Faktor afektif merupakan rangkaian dari seluruh respon atau tanggapan orang tua siswa, Dinas Pendidikan dan masyarakat. Adapun teknik pengumpulan datanya melalui: studi pustaka, wawancara, observasi, dan dokumentasi. Teknik analisisnya menggunakan cara-cara kualitatif yaitu dilakukan bersamaan dengan pengumpulan data dan pada bagian akhir data-data yang bersifat genetik, objektif dan afektif dikaji secara integratif.

\section{ANALISIS DAN INTERPRETASI DATA}

Pendekatan sebuah penelitian dengan struktur model kritik seni holistik merupakan model yang paling lengkap, karena memandang suatu karya, program atau peristiwa dan kondisi tertentu, kualitasnya harus didasarkan dan dirujuk dari latar belakang (faktor genetik), kondisi formal yang berupa kenyataan objektif (faktor objektif), dan hasil atau dampak dari tanggapan emosional atau persepsi orang yang berinteraksi dengan karya atau program yang dievaluasi (faktor afektif) (Sutopo, 2006:143-144). Untuk mengungkap pendidikan seni tari sebagai Pengembangan Karakter Anak di Sanggar Sarwi Retno Budaya dengan pendekatan model kritik holistik, kiranya perlu diungkap masing-masing faktor yang berkaitan dengan latar belakang pendiri perkumpulan sanggar seni, proses pembelajaran seni tari di sanggar dan persepsi masyarakat terhadap pembelajaran seni tari di Sanggar Seni Sarwi Retno Budaya.

\section{Faktor Genetik}

Faktor genetik adalah segala sesuatu yang berkaitan dan terjadi sebelum karya, konteks awalnya sebelum program terwujud dan juga proses pembentukannya (Sutopo, 2006: 144). Merujuk dari pernyataan tersebut kiranya dapat disarikan bahwa faktor genetik atau latar belakang merupakan sebuah konsep yang mampu menghasilkan dan mewujudkan bentuk objektif sebagai realitas formal. Konsep sanggar Sarwi Retno Budaya Surakarta secara operasional adalah membentuk suatu perkumpulan kesenian yang cerdas, kreatif, inovatif, mandiri dan berprestasi (Akta Notaris Perkumpulan Sanggar Seni Sarwi Retno Budaya Surakarta, pasal 4). Beberapa konsep yang tersurat dalam akta notaris pendirian perkumpulan sanggar seni Sarwi Retno Budaya Surakarta sebagai bentuk suatu perkumpulan kesenian yang cerdas, kreatif, inovatif, mandiri dan berprestasi, menunjukkan arah yang lebih komprehensif. Arah maksud dan tujuan sanggar tampak lebih operasinal sebagai pedoman kebijakan untuk memandu pelaksanaan pendidikan kesenian yang di dalamnya mengutamakan seni tari sebagai bahan pengajaran. Konsep tersebut merupakan gagasan operasional yang perlu diimplementasikan di dalam proses seluruh kegiatan pendidikan seni tari pada sanggar Sarwi Retno Budaya Surakarta.

Sanggar sebagai bentuk suatu perkumpulan kesenian yang cerdas menurut Hartono, bahwa sanggar dalam pembelajaran seni tari memilih jenis-jenis tari yang disesuaikan dengan kemampuan siswa dan jenjang umur (wawancara Februari 2018). Dari sejumlah siswa sebagai peserta didik yang mendaftar di sanggar seni Sarwi Retno Budaya dapat dikelompokkan menjadi tiga bagian, yaitu kelas: PAUD \& Taman Kanak-kanan, Sekolah Dasar, SMP \& SMA. Bagi kelas PAUD \& Taman Kanak-kanan diajarkan beberapa materi di antaranya: tari Bang-Bang Rahino, tari Bethuk, tari Bebek, tari Belalang, dan tari Semut. Karakter tari Bang-Bang Rahino menggambarkan sebuah permainan atau dolanan yang bernuansa riang, gembira. Selain itu tari tersebut juga mudah untuk dipelajari bagi anak-anak yang umurnya setingkat PAUD \& TK, karena geraknya sangat sederhana, geraknya diulang-ulang, dan musiknya dinamis dan membingkai gerak atau mungkus. Bagi kelas Sekolah Dasar materi yang diajarkan tari yang memiliki tema binatang, seperti: tari Merak, tari Pemburu Kidang, tari Kelinci, tari Kukila, tari Kupu, tari Jaranan atau tari Kuda-kuda, tari Angsa, dan tari Lutung. Jenis-jenis tari tersebut memiliki karakter lincah, gesit, dan dinamis. Bagi kelas SMP \& SMA materi pembelajaran diantaranya: tari Pejuang, tari Bajidor Kahot, tari Sancoyo Kusuma Wicitro dan tari Srikandi Mustakaweni. 
Sanggar sebagai bentuk suatu perkumpulan kesenian yang mandiri, artinya bahwa kehidupan dan regulasi sanggar Sarwi Retno Budaya dikelola secara swadaya oleh keluarga pasangan ibu Sarwi dan bapak Hartono suaminya. Terbentuknya sanggar adalah adanya dorongan dari S.Maridi sebagai empu tari gaya Surakarta yang pada saat itu juga menjabat sebagai Penilik Kebudayaan Kecamatan Serengan, di mana sanggar Sarwi Retno Budaya berdomisili. Bentuk kemandirian ini didorong dari niat yang kuat, ditunjukkan pada sikap dan langkah-langkah nyata dari pasangan Sarwi dan Hartono yang mendambakan sebuah sanggar yang mampu menghasilkan penari-penari yang berkualitas (Sarwi, wawancara Januari 2018).

Sanggar sebagai bentuk suatu perkumpulan kesenian yang berprestasi, bagi sanggar Sarwi Retno Budaya merupakan sesuatu yang terus diupayakan dan diperjuangkan terwujud. Menurut Ester Indrasari sebagai guru senior sanggar, bahwa kehadiran sanggar Sarwi Retno Budaya di tengah-tengah masyarakat Surakarta telah menunjukkan prestasinya yang cukup membanggakan (wawancara Januari 2018). Berdasarkan data yang tersurat pada profil sanggar Sarwi Retno Budaya, terdapat beberapa prestasi yang telah diraih sanggar baik pada ajang lomba maupun festival. Adapun prestasi yang dapat diraih sanggar Sarwi Retno Budaya, diantaranya: festival Wayang Bocah dan festival Kethoprak Pelajar.

\section{Faktor Objektif}

Faktor objektif adalah realita atau kondisi formal yang berupa segala sesuatu yang terjadi dan bisa ditangkap dengan indera pada karya, peristiwa atau program yang sedang dievaluasi (Sutopo, 2006:144). Pendidikan seni tari di Sanggar Sarwi Retno Budaya merupakan sistem pendidikan nonformal yang mampu mengembangkan bakat anak-anak di bidang seni tari. Bentuk pembelajarannya tampak bahwa guru memberikan bekal ketrampilan secara fisik berupa ketrampilan gerak, kelenturan, keseimbangan, kualitas gerak, sensitifitas atau kemahiran gerak serta hafalan tari. Pembelajaran berikutnya adalah pengajaran yang bersifat nonfisik, yaitu kecerdasan rasa, emosional dan bekal pengetahuan tentang mencipta sebuah karya tari. Secara objektif bentuk pembelajaran di sanggar Sarwi Retno Budaya mampu mendidik anak-anak dengan bekal ketrampilan secara fisik dan kecerdasan nonfisik sehingga membentuk calon-calon penari profesional (wawancara, Sarwi Januari 2018).

Untuk mengungkap esensi makna dalam proses pendidikan seni tari sebagai pengembangan karakter anak di sanggar Sarwi Retno Budaya, perlu dicermati nilai-nilai yang ditanamkan guru terhadap siswa selama proses pembelajaran berlangsung di sanggar. Bentuk nilai-nilai yang dimaksudkan adalah nilai-nilai yang mampu mendorong, membentuk dan mengembangkan karakter anak-anak. Diharapkan dengan pendidikan karakter tersebut anak-anak akan tumbuh menjadi orang yang dapat mengambil kepu- tusan dengan bijak dan mempraktikkan dalam kehidupan sehari-hari, sehingga mereka dapat memberikan kontribusi positif terhadap lingkungannya (Megawangi, 2004:95).

\section{Pendidikan Seni Tari Sebagai Pengembangan Nilai Spiritual}

Menurut Jassin \& Dian, spiritual atau spiritual Quotient adalah sebuah kecerdasan menetapkan suatu tindakan dan pemikiran sesuai dengan yang diridhai Allah (2016:vi). Kekuatan spiritual yang sangat besar terlahir dari kata hati nurani yang jernih dari petunjukNya. Untuk itu manusia dapat hidup hingga mencapai derajat sejahtera \& bahagia sejak di dunia hingga jangka panjang kehidupan di akhirat. Pada realitanya manusia bisa hidup tidak bisa lepas dengan materi, mereka membutuhkan sandang, pangan, papan untuk tempat tinggal, hiburan dan lainnya. Kebutuhan-kebutuhan yang sifatnya materi merupakan kebutuhan jangka pendek yang sifatnya sementara, namun tetap kita perlukan juga dalam rangka meraih kehidupan yang lebih kekal. Kesadaran yang perlu dipahami dan dicermati secara mendasar dan menyeluruh bahwa manusia hidup sesungguhnya sangat membutuhkan kebahagiaan. Kebutuhan-kebutuhan yang sifatnya batiniah, rohaniah, spiritual yang sifatnya nonmateri menjadi kebutuhan jangka panjang primer yang tidak terbatas. Semakin tampak bahwa baik kebutuhan materi maupun kebutuhan nonmateri menjadi sebuah keniscayaan dalam kehidupan manusia. Terutama kebutuhan yang sifatnya spiritual perannya menjadi sangat penting bagi pengembangan diri manusia.

Bentuk penanaman nilai spiritual dalam pendidikan seni tari di sanggar Sarwi Retno Budaya melalui tema-tema tari yang diajarkan. Jenis-jenis tari yang diberikan kepada siswa sebagai materi ajar, secara kuantitas didominasi tari-tarian yang bertemakan binatang. Kita mengetahui dan memahami bahwa makluk hidup ciptaan Allah SWT, di antaranya adalah manusia, tumbuh-tumbuhan, dan binatang atau fauna. Mempelajari tari-tarian yang bertemakan binatang merupakan usaha untuk mengenal dan mengetahui sifat-sifat makluk ciptaan Allah SWT. Menurut Thomas Lickona, bahwa pembelajaran nilai-nilai moral terhadap lingkungan biasanya mengarahkan anak-anak pada binatang, mengingat hampir seluruh anak secara psikologis memiliki empati alamiah pada binatang (2014:212). Perbuatan yang demikian itu merupakan salah satu cara atau langkah untuk mensyukuri dan mengagungkan anugerah Allah SWT. Pemahaman pengetahuan yang demikian itu merupakan cerminan pengembangan nilai spiritual anakanak sanggar dalam usaha pengembangan karakter.

\section{Pendidikan Seni Tari Sebagai Pengembangan Nilai Ke- jujuran}

Pemahaman nilai kejujuran dalam pembelajaran tari, dapat diamati ketika anak-anak menyajikan tari Kelinci, mereka dengan kejujurannya akan menyajikan tari tersebut baik secara hafalan urutan, bentuk vokabuler sekaran atau ragam geraknya, kesesuaian dengan musik dan penjiwaan 
peran tarinya sesuai dengan karakter Kelinci. Rupanya sangat tidak mungkin penjiwaan peran tari Kelinci tiba-tiba dirubah atau diganti ragam-ragam gerak atau sekaran dan penjiwaan karakter tari Kera. Berdasarkan gambaran peristiwa penyajian tari Kelinci, semakin tampak bahwa nilai kejujuran dalam pendidikan seni tari dapat dirujuk dari kejujuran ekspresi jiwa. Original ekspresi jiwa penari merupakan ungkapan yang bersifat bebas dan mandiri (Parker, 1980:24). Untuk itu tidak berlebihan bila kehadiran tari sebagai ungkapan ekspresi jiwa manusia merupakan media komunikasi untuk menyampaikan pesan-pesan dari seniman kepada penonton. Nilai kejujuran berupa perilaku perkataan, tindakan, perilaku dan pekerjaan yang dapat dipercaya dalam pendidikan seni tari tercermin pada Original ekspresi jiwa penari dalam menyajikan tari.

Pendidikan Seni Tari Sebagai Pengembangan Nilai Santun Santun dalam pandangan masyarakat merupakan bentuk tindakan atau perilaku yang beritika sopan, lemah-lembut dalam berbicara dan bergerak, dan lebih menghormati serta rendah hati. Menurut pandangan George Yule, bahwa tingkah laku sosial yang sopan atau etikat dalam budaya pada umumnya, menempatkan prinsip-prinsip yang bersifat umum, di antaranya: sifat bijaksana, pemurah, rendah hati, dan simpatik terhadap orang lain (2006:104). Penanaman nilai santun pada pembelajaran tari di sanggar Sarwi Retno Budaya, diajarkan guru terhadap para siswa dalam bentuk tindakan atau perilaku duduk bersimpuh ketika guru menerangkan pengetahuan tentang materi tari yang sedang diberikan maupun saat guru demontrasi memberikan contoh bentuk vokabuler gerak baik: urutan sajian, bentuk, irama dan kualitas. Selain itu nilai kesantunan juga ditanamkan melalui kebiasaan perilaku mencium tangan guru yang dilakukan siswa setiap saat ketemu dengan guru- guru sanggar. Nilai kesantunan juga diajarkan dalam berbicara terutama pada saat tanya jawab untuk menggunakan bahasa yang lembut, halus bukan bahasa yang kasar ngoko terutama ketika menggunakan bahasa Jawa. Para siswa juga dilarang berbicara keras yang membuat gaduh ataupun ramai, hal itu akan mengganggu kelas lainnya yang sedang proses pembelajaran, mengingat ruangan untuk latihan hanya satu yang digunakan secara bergantian.

\section{Pendidikan Seni Tari Sebagai Pengembangan Nilai Kerja Sama}

Pada dasarnya manusia hidup tidak mampu lepas dari lingkungan dan bertahan sendiri, betapapun hebat dan kuatnya. Ketergantungan antar individu merupakan faktor utama manusia untuk saling berkomunikasi dalam rangka meraih kehidupan yang berbudaya, sebagai sarana mewujudkan cita-citanya. Setiap individu yang lahir dalam masyarakat, dapat dikatakan belum mempunyai bekal, sehingga dia harus belajar menjadi manusia dengan menghayati atau mendalami budaya kelompoknya (Maryono, 2010:1). Sifat sosial manusia berasal dari kenyataan bahwa untuk menolong dirinya sendiri dalam aktivitas yang diperlukan untuk mempertahankan hidupnya, manusia harus men- yandarkan diri dengan orang lain (Lauer, 2003:43). Kerja sama dimulai dengan pengetahuan bahwa manusia hidup itu bersama dengan manusia lainnya dan bahwa di dunia orang-orang dan masyarakat semakin saling bergantung untuk itu kita harus bekerja sama ke arah tujuan-tujuan yang dasariah untuk survival manusia (Dharma Kesuma dkk, 2011:68). Berbagai strategi belajar untuk menjadi manusia yang diperlukan agar dapat terinkulturasi dan tersosialisasi sepenuhnya, untuk itu komunikasi dengan orang lain dalam rangka bekerja sama menjadi kebutuhan primer.

Nilai kerja sama juga ditanamkan pada siswa sanggar Sarwi Retno Budaya pada pementasan dramatari maupun karya-karya tari yang sifatnya kelompok hingga yang berbentuk massal. Karya-karya tari yang sifatnya kelompok dapat kita kenal dari tingkat kelompok yang paling kecil yaitu tari pasangan yang melibatkan dua penari, frahmen yang melibatkan minimal tiga penari hingga sekitar enam penari, dramatari yang melibatkan banyak penari hingga puluhan dan dramatari kolosal yang melibatkan puluhan hingga ratusan maupun ribuan penari (Maryono, 2015:811). Karya-karya tari kelompok yang dihasilkan atau diproduksi sanggar Sarwi Retno Budaya lebih berbentuk frahmen dan dramatari. Adapun bentuk kerja sama dalam karya tari kelompok ini lebih mengarah kerja sama terutama antar peran atau tokoh yang berkaitan dengan rasa sambung rapet untuk penyajian sebuah pertunjukan tari secara wutuh.

\section{Pendidikan Seni Tari Sebagai Pengembangan Nilai Tenggang Rasa}

Satu sumber nilai seni adalah kenikmatan yang diberikan oleh medium ungkapan yang tersusun dari warna, garis dan bentuk, bunyi kata atau nada, dengan irama dan hubungan-hubungannya (Parker, 1980:44). Kenikmatan yang diberikan oleh medium ungkapan atau bentuk objektif, tidak lain adalah kenikmatan rasa. Sebab ungkapan seni itu memang dimaksudkan supaya memiliki nilai sendiri yang melekat secara instrinsik, yang itu semua sengaja dibuat supaya menarik perhatian kita padanya. Seperti seni tari yang merupakan perpaduan dari berbagai medium ungkapan, yaitu: gerak sebagai garap tari, bunyi dan bahasa sebagai garap iringan, serta rupa sebagai garap rias dan busana, ini merupakan realitas kemunculan bentuk komplementer. Penafsiran terhadap keragaman medium ungkapan yang terdapat dalam tari tidak mampu ditangkap secara rasional semata tetapi ketajaman rasa merupakan ujung tombak dalam menangkap makna yang sebenarnya.

Pembelajaran seni tari di Sarwi Retno Budaya merupakan salah satu bentuk sarana pengembangan nilai tenggang rasa. Bentuk implementasinya nilai tenggang rasa dapat dilihat dan dicermati ketika siswa memanfaatkan sebagian waktu istirahat yang secara bersama-sama berusaha untuk menghafalkan materi-materi yang telah diberikan guru, mereka secara kondusif tenang tidak mengganggu pela- 
jaran kelas lainnya yang sedang melangsungkan kegiatan pembelajaran tari jenis lain. Selain itu pada tarian yang berpasangan seperti tari Sancoyo Kusuma Wicitra yang terdiri dari dua tokoh yaitu Prabu Sancoyo melawan Prabu Kusuma Wicitra, siswa harus mencermati dan menempatkan pola lantai secara cermat. Dalam tari Sancoyo Kusuma Wicitra, pola lantai atau posisi penari antara Prabu Sancoyo melawan Prabu Kusuma Wicitra harus terjaga jarak ideal baik waktu beksan maupun waktu perangan supaya tepat, sinkron, sambung dan harmonis. Harmonisasi penyajian tari Sancoyo Kusuma Wicitra secara menyeluruh, antar siswa sebagai pemeran kedua tokoh tersebut secara sungguh-sungguh dituntut untuk menggunakan tenggang rasa, karena jarak ideal antar penari bukan dihitung dari berapa centi meter ataupun berapa meter tetapi itu merupakan jarak ideal yang didasarkan pada kepekaan rasa. Cerminan nilai tenggang rasa ini juga terdapat pada bentuk-bentuk pola lantai pada jenis tari tunggal yang dalam penyajiannya dikelompokkan. Untuk itu kecermatan dan kemampuan memanfaatkan ketajaman rasa merupakan sumber pengembangan nilai tenggang rasa.

\section{Pendidikan Seni Tari Sebagai Pengembangan Nilai Di- siplin}

Menurut Sofyan, kedisiplinan menyangkut giatnya usaha dan memenuhi target serta waktu yang tepat (2013:155). Hal itu berarti disiplin dalam bekerja dan disiplin waktu. Dalam menanamkan nilai-nilai disiplin pada pembelajaran seni tari di Sarwi Retno Budaya, dapat kita cermati pada aktivitas siswa mempelajari tari terutama dalam menguasai gerak sekaran kaitannya dengan musik sebagai iringan. Dalam pertunjukannya tari hampir tidak pernah terlepas dengan kehadiran musik. Keberhasilan pertunjukan tari sangat ditentukan unsur medium bantunya yakni musik yang berfungsi sebagai iringan. Musik dalam tari mampu memberikan kontribusi kekuatan rasa yang secara komplementer menyatu dengan ekspresi tari sehingga membentuk suatu ungkapan seni atau ungkapan estetis. Bentuk penanaman nilai disiplin melalui pembelajaran seni tari di Sarwi Retno Budaya, teraktualisasi pada kesungguhan, ketepatan dan kedisiplinan siswa dalam menyambung dan mensikronkan gerak-gerak sekaran dengan musik. Kita perlu ketahui terlebih dulu bahwa masing-masing gerak sekaran memiliki pola-pola kendangan sebagai musiknya yang beragam pula. Seperti yang telah dinyatakan Maryono, bahwa membungkus/ mungkus pada konsep karawitan tari dimaksudkan membingkai terhadap gerak-gerik penari (2015:65-66). Adapun garapan gendhing sebagai pembingkai gerak-gerak penari terutama pada pola-pola gerak yang terdapat pada garap musik bagian kébar atau bagian yang bernuansa riang-gembira. Ketepatan dan kedisiplinan siswa dalam memperagakan gerak-gerak sekaran dengan pola-pola kendangan dari musik harus tepat baik panjang-pendeknya maupun nuansa atau rasa yang dikehendaki. Konsep irama yang harus tepat sesuai dengan ketukan balungan yang tidak dapat dimajukan maupun dimundurkan, konsep semacam ini dalam seni pertunjukan disebut irama midak.

\section{Pendidikan Seni Tari Sebagai Pengembangan Nilai Kreatif}

Pengembangan Nilai Kreatif melalui pembelajaran seni tari di Sarwi Retno Budaya, tercermin pada penyajian tari secara menyeluruh. Bentuk penyajian tari secara menyeluruh maksudnya bahwa penyajian tari tidak hanya menampilkan gerak, namun dalam penyajian seorang penari selain gerak, ia harus memakai busana, menggunakan rias dan memanfaatkan musik yang sesuai. Berkaitan dengan musik, mengingat tari yang dipelajari siswa-siswa sanggar adalah tari tradisi yang secara dominan mengakar dari tari budaya Karaton, maka musiknya merupakan hasil garapan dari gamelan yang berlaras slendro dan pelog. Pada akhir catur wulan atau akhir pemberian materi tari, seluruh siswa harus dievaluasi. Masing-masing siswa dalam kegiatan evaluasi, mereka harus menampilkan sebuah tari secara lengkap atau menyeluruh. Siswa dalam kegiatan evaluasi tidak sekadar memperagakan, mendemonstrasikan sebuah tarian pada tingkat hafal, benar dan bersih sebagai bentuk pembawaan, namun ia dituntut untuk menyajikan tari sesuai dengan karakternya (Erna Mia Piana, wawancara januari 2018). Artinya siswa dalam tampilan pada saat evaluasi tidak hanya pada tingkat membawakan sebuah tari, tetapi ia sudah dituntut menjadi seorang penyaji tari atau penari yang harus tampil dengan kualitas kepenarian sesuai dengan karakter tarinya. Untuk itu siswa sebagai penari harus kreatif untuk mampu menafsirkan karakter tari sehingga ia mampu menyajikan tari yang berkualitas. Penafsiran karakter sebuah tari, siswa harus menggunakan kerja kreatif pikir, perasaan dan kemampuan tubuh. Selanjutnya guru dalam proses pembelajaran tari, mengajak siswa untuk memasukkan perasaan atau emosinya secara total untuk menjiwai sebuah peran atau karakter tari. Hal itu sesuai dengan pernyataan bahwa seniman tidak menghadirkan benda secara objektif semata, namun ia menyajikan karyanya dengan kreativitas artistik (Sutopo, 1995:12-13).

\section{Pendidikan Seni Tari Sebagai Pengembangan Nilai Tanggungjawab}

Menurut Kamus Bahasa Indonesia, tanggungjawab berarti kewajiban terhadap segala sesuatunya; fungsi menerima pembebanan sebagai akibat sikap tindak sendiri atau pihak lain (Em Zul \& Ratu, hal:794). Tanggungjawab secara harfiah mempunyai arti kemampuan merespon. Maksud yang terkandung adalah berorientasi terhadap orang-orang lain, mencurahkan terhadap mereka, merespon secara aktif terhadap kebutuhan-kebutuhan mereka. Bentuk pertanggungjawaban menekankan pada kewajiban-kewajiban positif untuk saling menjaga antarorang (Dharma Kesuma dkk, 2011:67). Makna lain dari pertanggunganjawab adalah dapat dipercaya, tidak membiarkan orang lain mengalami kekecewaan karena ketidakkonsistenan kita. Kita menolong orang lain dengan cara memenuhi komitmen kita dan tidak menciptakan masalah baru ketika kita tidak me- 
menuhinya. Pertanggunganjawaban berarti pelaksanaan suatu pekerjaan atau tugas yang harus dikerjakan dengan sebaik-baiknya sesuai dengan kemampuan yang kita miliki.

Nilai tanggungjawab yang ditanamkan melalui pembelajaran seni tari di Sarwi Retno Budaya dapat dicermati pada setiap kegiatan mengawali proses pembelajaran. Setelah proses pembelajaran berlangsung, siswa akan mendapat suatu materi gerak sekaran yang merupakan bagian dari sebuah tarian. Kewajiban bagi siswa setelah mendapatkan materi dari seorang guru, ia harus menghafalkan sebagai salah satu teknik untuk menguasai materi. Tanggungjawab sebagai siswa setiap mengawali pertemuan siswa harus memperagakan atau mendemonstrasikan materi yang telah diberikan guru dengan hafal. Apabila dalam mendemonstrasikan materi tari tidak benar, siswa diminta untuk mengulangi dengan dipandu seorang guru. Merujuk dari penjelasan tersebut tampak bahwa siswa diberi beban tanggungjawab untuk menghafal materi. Diharapkan dengan tanggungjawab yang diberikan oleh seorang guru, siswa merasa mempunyai kewajiban bukan sebagai beban namun lebih dimaknai sebagai rasa tanggungjawab yang seharusnya dilaksanakan dan dikerjakan untuk menjadi seorang penari.

Penanaman nilai tanggungjawab melalui pembelajaran seni tari di sanggar Sarwi Retno Budaya juga tercermin pada kegiatan evaluasi sebagai akhir proses pembelajaran pada tiap-tiap catur wulan. Dalam rangka unjuk kerja sebagai presentasi akhir dari proses pembelajaran perlu penilaian hasil belajar baik formal maupun informal dilaksanakan dalam suasana yang menyenangkan, sehingga memungkinkan peserta didik menunjukkan apa yang dipahami dan mampu dikerjakan (Martinis \& Maisah, 2009:204). Bentuk penilaian atau evaluasi pada akhir catur wulan merupakan sebuah kegiatan untuk dapat menggambarkan sejauhmana seseorang peserta didik telah menguasai suatu kompetensi, untuk itu siswa harus unjuk kerja. Dalam kegiatan penilaian atau evaluasi pada akhir catur wulan, siswa sanggar harus unjuk kerja dengan cara menyajikan sebuah tari lengkap dengan busana, rias dan musik secara mandiri. Guru memberikan nilai nominal antara 60 hingga 90 dan beberapa catatan pada buku rapor.

\section{Faktor Afektif}

Faktor afektif merupakan dampak atau tanggapan beragam pengamat atau pribadi yang terlibat dan juga termasuk manfaat yang didapat darinya (Sutopo, 2006: 144). Hasil pengamatan, penilaian, dan analisis terhadap suatu karya, program ataupun peristiwa yang dilakukan beberapa orang hasilnya yang pasti tidak sama. Perbedaan-perbedaan yang muncul perlu disadari bahwa masing-masing individu memiliki bekal, kemampuan, kecerdasan dan keinginan yang beragam pula, sekalipun dalam satu objek permasalahan, fenomena ataupun peristiwa tertentu. Seperti keberagaman pendapat dari tanggapan masyarakat terhadap proses kegiatan pendidikan seni tari di sanggar Sarwi Retno Budaya. Keberagaman persepsi hasil dari tanggapan orang tua siswa, guru tari dan Dinas Pendidikan terhadap proses kegiatan pendidikan seni tari di sanggar dapat peneliti gambarkan sebagai berikut.

Tanggapan dari orang tua siswa yang lainnya muncul pendapat bahwa setelah anaknya masuk di sanggar Sarwi Retno Budaya tampak lebih rajin yang mengarah pada kedisiplinan. Beberapa sikap atau perilaku yang mencerminkan peningkatan kedisiplinan anak-anak, teraktualisasi pada kedisiplinan waktu. Kedisiplinan waktu yang tampak pada anak-anak, dimana mereka dapat membagi waktu untuk sekolah, waktu untuk kursus mata pelajaran umum, waktu untuk kursus menari dan waktu untuk bermain. Terutama waktu untuk berangkat ke sanggar untuk belajar seni tari, mereka sangat semangat. Rupanya dorongan atau motivasi yang kuat dan muncul pada anak-anak karena belajar seni tari memberikan nuansa kegembiraan sehingga membangun kesegaran jiwa menjadi lebih segar. Rangsangan estetis pada diri anak-anak mampu mengembangkan kecerdasan rasa yang pada muaranya secara berimbang dan bersinergi dengan kecerdasan intelektual mengembangkan dan membentuk karakter jiwa manusia. Persepsi guru seni, bahwa pendidikan seni tari di sanggar Sarwi Retno Budaya merupakan langkah yang sangat strategi untuk mengembangkan bakat-bakat seni pada anak-anak sehingga mampu mencetak penari-penari yang berkualitas. Sistem pendidikan seni tari di sanggar merupakan bentuk pendidikan seni nonformal yang secara spesifik, artinya siswa sebagai peserta didik lebih konsentrasi pada satu bidang tari, sehingga harapan keberhasilannya menjadi sangat besar. Konsentrasi para siswa sifatnya tunggal mengarah satu bidang seni tari yang harus dikuasai dengan sistem pembelajaran yang terstruktur yang tidak diformalkan. Dengan sistem pembelajaran yang terstruktur dengan mengkombinasikan beberapa metode yang diantaranya: metode ceramah, metode demonstrasi, metode imitasi, metode tanya jawab, metode drill, metode penampilan untuk membentuk dan mencetak penari yang berkualitas dan menggunakan metode studi mandiri sebagai cara untuk mengevaluasi adalah sebuah sistem pendidikan sanggar dalam rangka menghasilkan calon-calon penari-penari yang profesional.

Pandangan dari Pakar seni, pengalaman bergulat dengan seni baik secara fisik maupun nonfisik yang berorientasi pada cipta rasa keindahan yang dilakukan siswa secara terus-menerus, berkesinambungan itu akan membentuk jiwa-jiwa seni yang tangguh. Bertolak dari pengalaman mengenyam pendidikan di bidang seni tari tersebut secara linier terbentuk jiwa-jiwa apresiator seni dan menghasilkan calon-calon seniman yang berbobot. Diharapkan dari seniman-seniman muda berbakat inilah merupakan aset bangsa yang mampu menjaga dan melestarikan budaya Indonesia. Mereka akan merasa bangga terhadap budaya yang dimiliki yang secara otomatis akan menjadi filter 
bagi budaya asing yang tidak sesuai dengan peradaban budaya kita. Dengan demikian keberadaan sanggar dengan segala aktifitasnya dan seluruh prestasinya merupakan pusat budaya dan benteng budaya yang kokoh dalam rangka menjaga, melestarikan dan mengembangkan peradaban budaya bangsa Indonesia.

Berdasarkan penjelasan asas \& dasar serta maksud dan tujuan membentuk perkumpulan kesenian dapat ditarik konsep genetiknya bahwa Perkumpulan Sanggar Seni Sarwi Retno Budaya berasaskan Pancasila dan berdasarkan Undang-undang Dasar 1945 untuk mewujudkan nilai-nilai: religius atau spiritual, humanisme, persatuan, demokratis, keadilan, kemerdekaan, kedaulatan, kemakmuran, cerdas, kreatif, inovatif, mandiri dan berprestasi dengan mengembangkan bakat anak-anak sebagai generasi penerus bangsa dalam rangka melestarikan budaya tradisi. Secara objektif pendidikan seni tari sanggar seni Sarwi Retno Budaya merupakan suatu sistem pendidikan nonformal yang mampu menghasilkan penari-penari profesional yang memiliki nilai-nilai karakter: spiritual, kejujuran, santun, kerja sama, tenggang rasa, disiplin, kreatif, dan tanggungjawab. Secara afektif tampak bahwa pendidikan seni tari sanggar seni Sarwi Retno Budaya mampu mendidik seniman-seniman muda berbakat sebagai generasi penerus yang mampu menjaga, melestarikan dan mengembangkan peradaban budaya bangsa Indonesia. Secara holistik pendidikan seni tari sanggar seni Sarwi Retno Budaya merupakan sistem pendidikan nonformal yang mampu mendidik anak-anak menjadi calon-calon penari profesional yang memiliki nilai-nilai karakter: spiritual, kejujuran, santun, kerja sama, tenggang rasa, disiplin, kreatif, dan tanggungjawab untuk menjaga, melestarikan dan mengembangkan peradaban budaya bangsa Indonesia.

\section{SIMPULAN}

Berdasarkan kajian secara holistik keterkaitan tiga faktor: genetik, objektif, dan afektif dapat ditarik simpulannya bahwa pendidikan seni tari di sanggar seni Sarwi Retno Budaya mampu mendidik calon-calon penari profesional yang memiliki nilai-nilai karakter sebagai pengembangan karakter anak supaya memiliki kepribadian yang bertanggungjawab untuk menjaga, melestarikan dan mengembangkan peradaban budaya bangsa Indonesia. Adapun nilai-nilai karakter yang ditanamkan terhadap anak-anak atau siswa sanggar seni Sarwi Retno Budaya yaitu: nilai spiritual, nilai kejujuran, nilai santun, nilai kerjasama, nilai tenggang rasa, nilai disiplin, nilai kreatif, dan nilai tanggungjawab.

Pendidikan seni tari di sanggar seni Sarwi Retno Budaya mampu mengembangkan nilai-nilai karakter anak, yaitu: (1) nilai karakter spiritual yang dapat dicermati melalui kegiatan doa sebelum dan sesudah pembelajaran tari. Selain itu melalui beragam tema binatang dari jenis-jenis tari yang digunakan sebagai materi pembelajaran. (2) Nilai karakter kejujuran dalam pendidikan seni tari dapat dirujuk dari kejujuran ekspresi jiwa yaitu original ekspresi jiwa penari dalam menyajikan tari. (3) Nilai karakter santun tercermin pada tindakan atau perilaku siswa duduk bersimpuh ketika guru menerangkan. Selain itu kesantunan juga ditanamkan melalui kebiasaan perilaku mencium tangan guru dan pada saat tanya jawab untuk menggunakan bahasa yang lembut, halus bukan bahasa yang kasar atau ngoko. (4) Nilai karakter kerjasama dapat dicermati pada kerja kelompok siswa untuk menghafalkan materi dan juga kerjasama antar peran atau tokoh dalam sebuah karya Dramatari, Kethoprak maupun Wayang Bocah. (5) Nilai karakter tenggang rasa merupakan sikap toleran yang suka menghargai dan mendahulukan kepentingan umum yang dapat diamati pada kegiatan kerja kelompok yang tidak mengganggu kelompok lainnya. Nilai karakter tenggang rasa juga ditanamkan melalui implementasi penataan pola lantai antarpenari. (6) Nilai karakter disiplin teraktualisasi pada kesungguhan, ketepatan dan kedisiplinan siswa dalam menyambung dan mensikronkan gerak-gerak sekaran dengan musik. Kegiatan kedisiplinan berikutnya adalah kemampuan siswa dalam menyerap dan menguasai materi tari dengan mengimitasi gerak tari sesuai yang diajarkan guru. (7) Nilai karakter kreatif tercermin pada kemampuan siswa untuk menafsirkan karakter masing-masing tari sehingga ia mampu menyajikan tari yang berkualitas sesuai dengan karakter perannya. Kerja kreatif dalam pendidikan seni tari harus menggunakan kerja pikir, perasaan atau emosional dan kemampuan ketrampilan tubuh sebagai penyaji atau penari. (8) Nilai karakter tanggungjawab ditanamkan pada siswa untuk selalu siap hafal materi setiap tatap muka dan saat evaluasi siswa harus unjuk kerja dengan cara menyajikan sebuah tari lengkap dengan busana, rias dan musik secara mandiri. Bentuk tanggungjawab yang lain yaitu tertib administrasi, dimana siswa pada setiap bulan harus membayar sebagai kompensasi ilmu yang diterima.

Diharapkan dari seniman-seniman muda berbakat dan berkarakter inilah merupakan aset bangsa yang mampu menjaga dan melestarikan budaya Indonesia sebagai rasa tanggungjawab anak-anak bangsa. Dengan demikian kehadiran sanggar seni Sarwi Retno Budaya sebagai wahana pendidikan nonformal kesenian dengan segala aktifitasnya dan seluruh prestasinya merupakan salah satu pusat budaya dan benteng budaya yang kokoh dalam rangka menjaga, melestarikan dan mengembangkan kebudayaan tradisi sebagai manifestasi pengembangan peradaban budaya bangsa Indonesia.

\section{DAFTAR RUJUKAN}

Cahya. (2016). Nilai, Makna, dan Simbol Dalam Pertunjukan Wayang Golek Sebagai Representasi Media Pendidikan Budi Pekerti. Panggung, 26, (2), 117-127. 
Kesuma, Dharma dkk. (2011). Pendidikan Karakter. Bandung: PT Remaja Rosdakarya.

Maryono. (2010). Komponen Verbal Dan Nonverbal Dalam Genre Tari Pasihan Gaya Surakarta (Kajian Pragmatik). (Doktor/ Dr), Program Pascasarjana, UNS.

Maryono. (2010). Pragmatik Genre Tari Pasihan Gaya Surakarta. Surakarta: ISI Press Solo.

Maryono. (2015). Analisa Tari. Surakarta: ISI Press Solo. Megawangi, Ratna. (2004). Pendidikan Karakter: Solusi yang Tepat Untuk Membangun Bangsa. Bogor: Indonesia Heritage Foundation.

Lickona, Thomas. (2008). Educating for Character. Diterjemahkan oleh. Lita. S. 2014. Pendidikan Karakter. Bandung: Nusa Media.

Parker, De Witt. H. (1920). The Principle of Aestetics. Diterjemahkan oleh. S.D Humardani. 1980. Dasar-dasar Estetika. Surakarta: Akademi Seni Karawitan Indonesia (ASKI).

Saptono. (2011). Dimensi-Dimensi Pendidikan Karakter. Jakarta: Erlangga.

Suhartono, Suparlan. (2008). Filsafat Pendidikan. Yogyakarta: Ar-ruzz Media.

Sutopo, H.B. (1995). Kritik Seni Holistik Sebagai Model Pendekatan Penelitian Kualitatif. Surakarta: Sebelas Maret University Press.

Sutopo, H.B. (2006). Metodologi Penelitian Kualitatif Dasar Teori dan Terapannya dalam Penelitian. Surakarta: UNS.

Yule, George. (1996). Pragmatics. Diterjemahkan oleh. Indah Fajar Wahyuni. 2006. Pragmatik. Penerbit: Pustaka Pelajar. 